\section{GM salmon declared fit for dinner plates}

Genetically modified (GM) salmon was finally approved in November for commercial sale in the US - the first GM animal to be approved for human consumption. The fate of the fish, developed by Maynard, Massachusettsbased AquaBounty Technologies, had been in regulatory limbo at the US Food and Drug Administration (FDA) since 1995. Animal geneticists say the long-awaited green light may open the door for the rest of the field. "It's a great moment," says Bruce Whitelaw, professor of animal biotech at the Roslin Institute at the University of Edinburgh in the UK. "The whole world has waited and watched to see what would happen."

Meanwhile, opponents of the fish have vowed to sue the FDA in an attempt to block its decision. And Congress in December passed legislation that would forbid sale of the salmon in the US until the FDA finalizes labeling guidelines and a program for informing the public.

AquaBounty's product, dubbed AquAdvantage salmon, is engineered to produce sustained low levels of growth hormone, enabling it to reach market size about twice as fast as conventionally farmed Atlantic salmon, according to the company. The fish was transformed with a growth hormone gene from Chinook salmon controlled by an antifreeze protein promoter and a terminator from ocean pout. The construct was first demonstrated in salmon in 1989.

Few companies have the ability to survive 20 years in regulatory limbo. Indeed, AquaBounty nearly folded on several occasions. "For about three years in a row we came within a few weeks of being insolvent," says Ron Stotish, $\mathrm{CEO}$ at AquaBounty. "Each time we managed to pull a rabbit out of the hat." It helps to have a billionaire-owned company as a majority

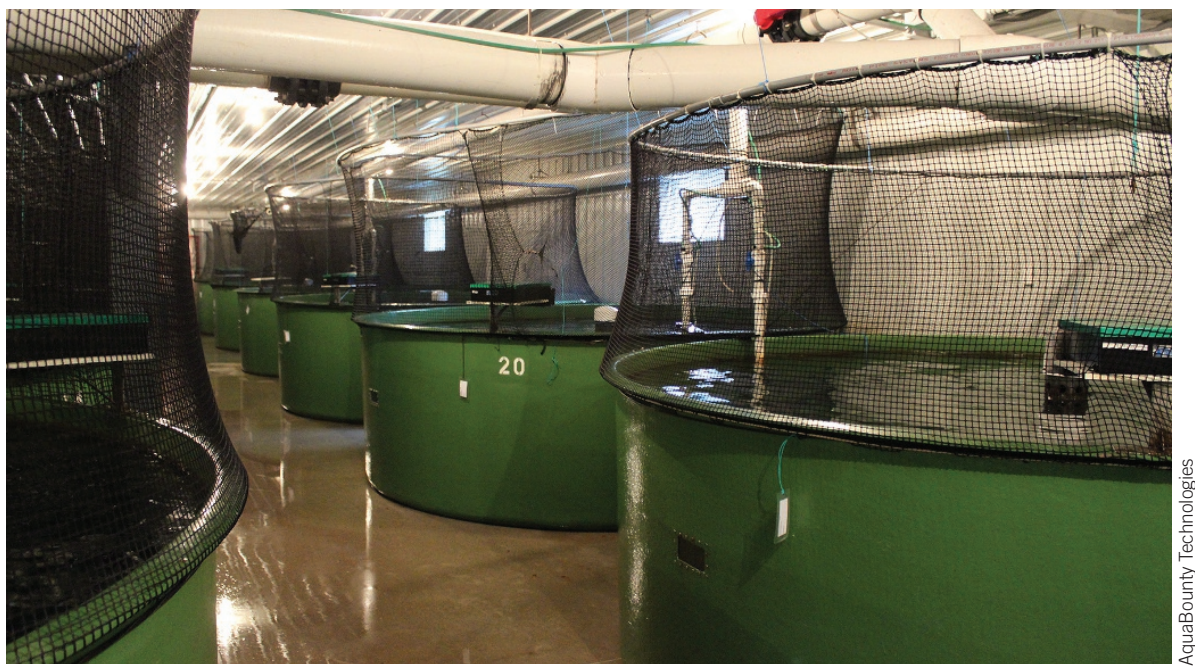

shareholder-Randal J. Kirk's Germantown, Maryland-based Intrexon-that tends to take the long view (Nat. Biotechnol. 33, 1017-1018, 2015). Intrexon first stepped in in 2012 after one of AquaBounty's important shareholders bailed.

AquaBounty wasn't alone in its hardships. The regulatory standstill has made animal biotechnologists question the commercial feasibility of GM animals. "There's been a suppression of the whole field because of this," says Whitelaw, who is developing virus-resistant pigs. "It has been difficult to get commercial backing and government funding because you come up against the argument that the product will never come to market," he says. The delay also greatly depressed the ability to innovate or recruit young researchers to the field, says James Murray, an animal geneticist at the University of California, Davis, who is developing transgenic goats that produce in their milk an antibacterial protein that can prevent diarrhea. "We thought we'd be on version 2.0 or 3.0 of animals in agriculture. We're still on version 1.0. They are the genetically engineered equivalent of your old flip phones," Murray says.

The regulatory obstacles for salmon started before the process officially began. AquaBounty, originally known as A/F Protein, began discussions with regulators in 1993, but at the time, no defined regulatory pathway existed for GM animals (Nat. Biotechnol. 29, 706-710, 2011). The company in 1995 opened an investigational new animal drug file with the FDA for the salmon, but the agency still wasn't close to knowing what kind of data it would want to request from applicants. It wasn't until 2009 that the agency was able to finalize guidelines indicating what would be required in a GM animal application process.

AquaBounty's application wasn't being ignored during that time, say some researchers

\title{
Shire bites deeper into rare disease space
}

Dublin-based Shire has agreed to buy Dyax, a company with a rare disease treatment that bolsters its current portfolio in hereditary angioedema (HAE). With the proposed \$5.9-billion acquisition of the Burlington, Massachusetts, company, Shire gets its hands on a drug to prevent attacks of HAE, adding to its existing franchise, which includes approved drugs Firazyr (icatibant), used to treat acute attacks of $\mathrm{HAE}$, and Cinryze (C1 esterase inhibitor) for preventing such attacks. HAE is a rare genetic disease of the immune system that can cause spontaneous swelling anywhere in the body. It results from a deficiency of $\mathrm{C} 1$ esterase inhibitor activity, which in turn inhibits the activity of plasma kallikrein ( $\mathrm{pKal}$ ), a mediator of inflammation and other serine proteases in the blood.

Dyax's antibody DX-2930, a long-acting injectable pKal inhibitor in phase 3 testing, would compete with and presumably supplant Cinryze, Shire's second-biggest drug, based on DX-2930's more convenient dosing and a more favorable cost of goods. Sales of Cinryze, priced upwards of $\$ 400,000$ per year per patient, totaled $\$ 187.5$ million for Shire in the third quarter of 2015 , or $11.8 \%$ of total product sales. With Firazyr, the HAE franchise comprised $19.7 \%$ of product sales for the company. Dyax also brings to the table its approved pKal inhibitor Kalbitor (ecallantide) for treating acute attacks of HAE, but sales of that drug, which was first approved in 2009 , are modest, ringing in at just under $\$ 18$ million for the third quarter of 2015. Dyax is the latest in a string of multibillion-dollar acquisitions helping Shire maintain its position as the leading pharma firm squarely focused on rare diseases. Shire acquired Cinryze in a \$4.2-billion buyout of Exton, Pennsylvania-based ViroPharma in November 2013. In January 2015, it paid more than $\$ 5$ billion in cash for NPS Pharma (Nat. Biotechnol. 33, 226, 2015). Shire is also currently stalking Baxter International spinout Baxalta, in Deerfield, Illinois. In August 2015, it made a hostile offer of roughly $\$ 30$ billion for the biologics-oriented maker of orphan drugs in hematology, oncology and immunology. "Just focusing on cost scares me. It will undoubtedly disincentivize innovation." Hans Bishop, CEO of Juno Therapeutics in Seattle, which is developing cancer treatments based on engineering immune-system cells. (Forbes, 3 December 2015)

"Common sense and scientific logic says that it is impossible to have two identical plants where growth of one is, in reality, forbidden while the other can be grown with no restrictions." Stefan Jansson, professor at Umeå Plant Science Centre, speaking of plants modified with gene editing tools. In December, the Swedish Board of Agriculture declared that some plants edited by CRISPR/ cas 9 are not GMO by definition. (Umeå Plant Science Center News, 7 December 2015)

Fish hatchery tanks in AquaBounty's hatchery facility, PEI, Canada. 